\title{
Analysis on the Potential of the Implementation of Electric Power Substitution in Rural Energy System
}

\author{
Zhang Caiqing $^{1}$, \\ ${ }^{1}$ School of Economics and Management ,North \\ China Electric Power University, \\ Baoding 071000,China
}

\author{
Zeng Huan $^{1}$ \\ ${ }^{1}$ School of Economics and Management ,North \\ China Electric Power University, \\ Baoding 071000,China
}

\begin{abstract}
On the basis of China's rural energy consumption data from 1996 to 2010, the paper studies the terminal energy consumption in rural areas .Although firewood, straw, coal is still the main varieties of energy consumption in rural areas, but the potential of electric power and other clean energy is better. Then, it proposed the calculation method of electric power substitution, which can measure the size of its potential through converting other non-electric energy consumption into electricity value. in the end,we give suggestions about electric power substitution.
\end{abstract}

Key words:rural energy ; electric power substitution ; the analysis of potential;

\section{Introduction}

Rural energy substitution refers to using electric energy to replace firewood, straw, rural regular terminal energy sources such as coal, petroleum products in order to improve the rural energy consumption structure and to slow down the environmental pollution.Rural energy substitution object does not include methane, biogas for straw, firewood, coal and other end-use energy,and it can not only replace them, but also mitigating the adverse effects on the environment [1].Despite China's rapid economic development over thirty years, most rural households still rely heavily on traditional biomass
sources.Kitchen hot water and heating energy consumption in rural areas, mainly depend on straw, firewood, and the use of renewable energy is very low [2], this irrational energy consumption structure caused serious pollution of people's living environment $[3,4]$.In order to protect the environment and people's health in rural areas, it is necessary to promote electricity as a substitution for firewood straw, coal to increase the proportion of electricity in the rural energy consumption.About energy substitution to other energy sources, domestic and foreign scholars have done some research. NH Ravindranath [5], who analyzed crop residues, animal manure, firewood development potential, believes that it should be given priority to India's future use of renewable energy as a new energy generation. By analyzing the local Spanish wind and solar power to understand the local related industries, Pablo delRio, Unruh G. [6] proposed to increase subsidies, the provision of credit and other national development policies to promote substitution energy sources. Zhu Chengzhang's research [7] showed that it has begun to focus on economic efficiency, energy efficiency and environmental benefits of energy when clean and renewable energy has become a substitution energy for minerals. Zhuang Fengfei [8] claim that it should open up the electricity market to promote means and methods. According to studies of energy consumption in the capital Beijing,Niu Dongxiao,Zhang Ye $[9,10]$ analyze electricity consumption in the final 
energy usage and the importance of electric power substitution.

Comprehensively therefore, the related study mostly focus on promoting rural energy structure optimization, rural energy consumption structure, economic environmental benefits, as well as alternative energy research in urban areas, while research on electric power substitution for final energy consumption in rural areas is little. To mitigate haze problem, electric power substitution in the final energy problems in rural areas should be studied.

\section{Position of electricity in rural end-use energy}

Straw consumption has been rising since 1996, which has accounted for more than $45 \%$ of total energy consumption in rural areas. straw will remain as one of the main source of rural energy consumption during a considerable period .Firewood in the early 1990s as China's second largest source of energy in rural areas, the proportion of consumption increasingly decreases, falling from 32.6 percent in 1996 to 31.0 percent in 1999, but the proportion in 2000-2002 has some rising since it has been reduced to 27.1 percent in 2010. As of rural life in the third largest energy source, coal consumption ratio has remained at around $15 \%$. Straw, firewood and coal constitute the sources of rural household energy body, whose proportion of consumption accounted for more than $85 \%$ of total energy. In rural China, the absolute amount of life electricity consumption had a rapid growth, but its share of total energy consumption in the proportion of rural life is still relatively low. electricity consumption rural areas . Comprehensively, the power as a clean energy, due to the ease of its use, will make consumption proportion steadily risen. in the future, with China's rural per capital income increasing and the effect of environmental awareness and other positive factors in the rural ,electricity is bound to make significant progress. From the trend of consumption, the level of energy consumption in rural areas, the total amount is bound to rise, and will be more convenient and clean power development in the structure.

\section{3 the potential of the implementation of electric power substitution in rural energy system}

\subsection{Major energy-consuming equipment and its efficiency}

Rural household energy consumption include the main different transportation, kitchen hot water (stove, stove, gas stove, LPG stove), heating (stove, stove, air conditioning), lighting and home appliances. Different energy use is through various energy-consuming equipment to achieve .otherwise, different energy devices consume different energy sources and consumption efficiency of different energy sources vary.each energy efficiency equipment is shown in Table 1 as can be seen from Table 1, the consumption efficiency of electrical devices is up to $100 \%$, while other energy efficiency of energy-consuming equipment were lower, both at $50 \%$ or less. 
Tab 1 . The efficiency of energy equipment

\begin{tabular}{|c|c|c|c|}
\hline use & energy equipmen & t energy type & efficiency \\
\hline \multirow{2}{*}{ transportation } & motorcycle & gasoline & 30 \\
\hline & car & gasoline & 30 \\
\hline \multirow{4}{*}{ heating } & coal stove & coal & 50 \\
\hline & stove & Firewood,straw & 50 \\
\hline & improved stoves & Firewood,straw & 50 \\
\hline & air conditioning & electricity & 100 \\
\hline \multirow{10}{*}{ kitchen and ho } & coal stove & coal & 22 \\
\hline & stove & firewood, straw & N 15 \\
\hline & improved stoves & firewood, straw & $\leqslant 27$ \\
\hline & gas stove & biogas & 45 \\
\hline & $\mathrm{t}$ LPG & LPG & 50 \\
\hline & hoods & electricity & 95 \\
\hline & cooker & electricity & 95 \\
\hline & ventilator & electricity & 95 \\
\hline & water Heater & electricity & 95 \\
\hline & microwave & electricity & 95 \\
\hline \multirow{3}{*}{ lighting } & incandescent & electricity & 95 \\
\hline & fluorescent & electricity & 95 \\
\hline & CFL & electricity & 95 \\
\hline \multirow{2}{*}{ refrigeration } & air conditioner & electricity & 95 \\
\hline & fan & electricity & 95 \\
\hline \multirow{3}{*}{$\begin{array}{l}\text { household } \\
\text { appliances }\end{array}$} & $\mathrm{TV}$ & electricity & 95 \\
\hline & refrigerator & electricity & 95 \\
\hline & washing machine & electricity & 95 \\
\hline
\end{tabular}

\subsection{Power substitution potential calculation method for final energy}

According to the analysis above, the power plant efficiency is $95 \%$. After all kinds of non-electric energy corresponding coal conversion coefficient given, then divided by the scale factor and folding efficiency of consumption of energy-consuming equipment , corresponding energy consumption efficiency,and the energy consuming devices, thereby we get converted energy value of rural non-electric energy. Power equipment efficiency is $95 \%$, so the potential for substitution energy in the final energy in the rural areas can be drawn according to the following formula:

$$
E=\frac{\sum_{f} \sum_{a} E_{f}^{a} \cdot \alpha_{\mathrm{f}} \cdot \eta_{\mathrm{f}}^{\mathrm{a}}}{\alpha_{\mathrm{E}} \cdot 95 \%} \cdot N
$$

Where, $\mathrm{E}$ is energy conversion of electric energy for other final energy, kw.h; $f$ : Non-power energy sources, including firewood, straw, coal, gasoline, liquefied petroleum gas, etc; $a$, the type of energy-consuming equipment; $\quad E_{f}^{a}$ : The average energy consumption of a device corresponds to the energy consumption in kind,kg ; $\eta_{\mathrm{f}}^{\mathrm{a}}:$ a consumption efficiency of energy-consuming equipment of the energy, $\% ; \alpha_{\mathrm{f}}$ is the scale factor of Non-electric energy resources , $\mathrm{kgce} / \mathrm{kg} ; \boldsymbol{\alpha}_{\mathrm{E}}$ is the scale factor of electricity, kgce / $\mathrm{kg} ; N$ is The actual number of households in rural areas.

\section{Example analysis}

Some county in HeBei is a traditional agricultural county, and the county has a total of 53,400 households, which accounted for about 89.5 percent of the rural population. the county's energy shortages, mainly living energy in rural areas derived from readily available straw, firewood and other biomass and coal. From different regions and different income levels, 540 specific data on the energy consumption of user representative 40 villages, is shown in Table 2, Table3.,Table 4.

In order to better compare the number and consumption of energy resources, all kinds of energy 
resources units are converted into standard coal equivalent standard coefficient according to the national unified standard .

Study results show that the implementation of substitution for rural energy has great potential ,annual substitution energy for other energy conversion energy value reached 321 million kw.h.

Tab 2.the average household consumption of energy resources in kind

\begin{tabular}{|c|c|c|c|c|c|c|}
\hline energy & \multicolumn{2}{|c|}{$(\mathrm{kg})$} & $\begin{array}{l}\text { Straw } \\
(\mathrm{kg})\end{array}$ & $\begin{array}{l}\text { coal } \\
(\mathrm{kg})\end{array}$ & $\begin{array}{l}\text { LPG } \\
(\mathrm{kg})\end{array}$ & $\begin{array}{r}\text { gas } \\
(\mathrm{kg})\end{array}$ \\
\hline $\begin{array}{l}\text { consumptiol } \\
\text { kind }\end{array}$ & in 1023.20 & 11 & 179.9 & 903.21 & 15.9 & 62.9 \\
\hline Tab 3.The & fold scalin & g facto & tor of rur & ral energ & & \\
\hline energy & firewood & straw & $N$ coal & LPG & gasoline & e electricity \\
\hline $\begin{array}{l}\text { conversion } \\
\text { factor }\end{array}$ & 0.571 & 0.5 & 0.714 & 1.714 & 1.4714 & 0.1229 \\
\hline
\end{tabular}

\section{Conclusion}

The research proposed a calculation method of the electric power substitution for rural energy . Studies have shown that: in 1996--2010 firewood, straw, coal accounts for the proportion of total energy consumption in rural areas are more than $80 \%$, which are the main source of household energy consumption in rural areas.what's more, the paper proposed calculation method of the potential for substitution energy in the final energy in rural areas.
Tab.4 the average household consumption of non-electric energy in kind

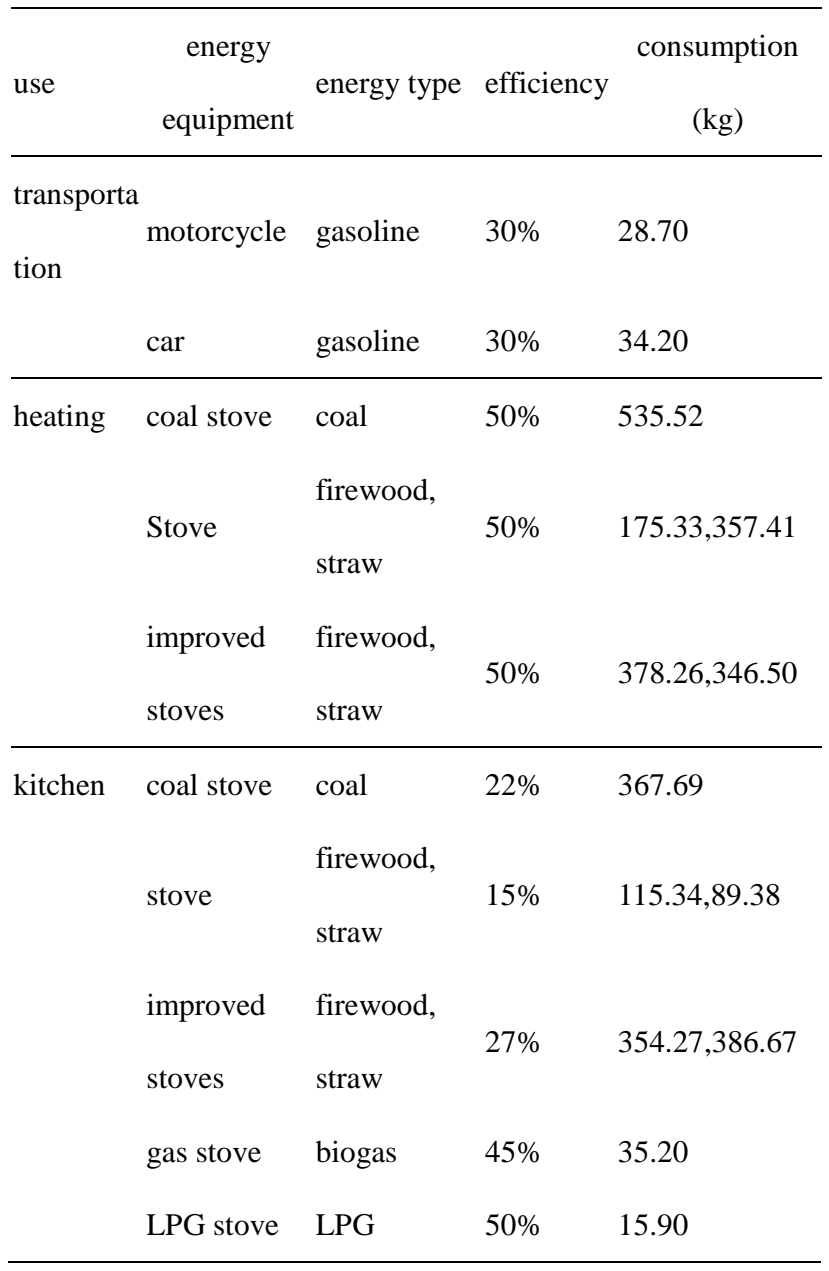

\section{Recommendations}

Based on these findings, the implementation of electricity substitution for rural energy has an important significance in the rural energy consumption,and we should actively promote this work.On one hand, the relevant government departments should make energy policies as soon as possible to encourage the implementation of rural energy consumption, such as economic subsidies, tariff concessions, support for alternative energy and other reconstruction projects.On the other hand, promoting rural electrification and promote the use of household appliances. The power companies and appliance companies buy home appliances to be some cooperation on economic subsidies by 
reducing the purchase cost of electrical equipment, so as to promote power substitution.

\section{References}

[1] Shao Qing, Song Dan, Yang Jin.Household Inventory Reduction and Environmental Benefits Analysis [J] . China Population, Resources and Environment ,2012, (08):76-83.

[2] Luo Guoliang, Zhang Yuanmin. Rural Energy Consumption of China [J].Chinese Agricultural Science ,2008(12): 535-540.

[3] Yan Lizhen, Min Qingwen. Chinese Rural Life Energy and Biomass Energy Development [J]. Resource Sciences, 2005,01: 8-13.

[4] Shaochao Feng, Zhang Yufen, Ju Meiting. China's Energy Consumption and Energy Saving Countermeasures[J]Resources Scientific. 2008.12: 1796-1802.

[5] N.H.Ravindranath,H.LSomashekar ,M.S.Nagaraja. Assessment of Sustainable non-Plantation Biomass Resources Potential for Energy in India [J].Biomass and Bioenergy,2005,29(3):178-190.

[6] Pablo delRio, Unruh G. Overcoming the Lock-out of Renewable Energy Technologies in Spain: The Cases of wind and Solar Electricity [J].Renewable and Sustainable Energy Reviews, 2010, 11(7):1498-1513.

[7] Zhu Chengzhang. Electricity Substitution, Power and Economy [J] . Coal Economic Research, 2011(08): 12-14.

[8]Shiquan Sheng ,Chuang Fengfei .Energy Substitution and Electricity Market Development [J] . Shanghai University of Electric Power, 2006(01): 97-100.

[9] Zhang Ye, Gu Zhihong Study on Energy Substitution in the Final Energy [J] ,Modern Economic: the Modern Property Fortnightly,2008(S1): 61-62.

[10] Zhang Ye .Competitiveness Evaluation of Beijing in Final Energy Consumption Evaluation [D] Energy Beijing: China Electric Power University, 2009.

[11] China's National Bureau of Statistics China Energy Statistical Yearbook [M] Beijing: China Statistics Press, 2011.

[12] China's National Bureau of Statistics China Statistical Yearbook countryside [M] Beijing: China Statistics Press, 2011.

[13] International Energy Agency IEA STATISTICS [M] .Paris: IEA Publication, 2012. 